\title{
THE EFFECT OF BREASTMILK TOPICAL ON PERINEAL WOUND HEALING ON 1-7 DAYS POSTPARTUM MOTHERS
}

\author{
Shinta Nuraini ${ }^{1)}$ Siti Saadah. ${ }^{2)}$ Sariestya Rismawati ${ }^{3)}$ \\ sn.shintanuraini@gmail.com \\ Health Polytechnic of Tasikmalaya \\ Midwifery Department
}

\begin{abstract}
Background: One of the causes of puerperal infection can start from the perineal wound which is not treated properly. The management of perineal wounds can be done pharmacologically and non-pharmacologically. One of non-pharmacological management is by using breastmilk as a topical agent because it contains anti-inflammatory molecules, bioactive substances and growth factors which are very useful for wound healing and prevent infection.

Purpose: This study aims to determine the effect of breastmilk topical of perineal wound healing on 1-7 days of postpartum mother in Mangkubumi Health Center of Tasikmalaya. Methods: This research was a Static Group Comparison design with the pre-experimental approach. The population in this study was 70 mothers who gave birth in December 2018 - February 2019 in Mangkubumi Health Center. The sampling technique in this study used purposive sampling and obtained as many as 60 people.

Results: The results showed a good wound healing process can be seen in the intervention group at the end of the assessment as many as $66.7 \%$ and $33.3 \%$ showed insufficient wound healing. Different from the control group that showed 36.7\% of good wound healing and $63.3 \%$ showed insufficient wound healing. Chi-square test showed a significant difference with $\rho$-value $(0.039)<\alpha(0.05)$.

Conclusion: The Effect of breastmilk topical of perineal wound healing on 1-7 days of postpartum mothers was evidenced. This study can be a reference for knowledge improvement in subsequent research.
\end{abstract}

Keyword : breastmilk, breastmilk topical, perineal wound healing

1) Student of DIV Midwifery Study Program, Health Polytechnic of Tasikmalaya

${ }^{2,3)}$ Lecturer at the Midwifery Department, Health Polytechnic of Tasikmalaya

Background. Maternal Mortality Rate (MMR) in the world by the United Nations MDG 2015 is equal to 216 per 100000 live births $(95 \%)$ of 800 maternal mortality rates per day occurs in developing countries.

One of the causes of maternal death due to the infection is poor perineal wound care management. The genesis of rupture perineum is still high in Asia, it reaches $50 \%$ of mothers giving birth vaginal delivery. In Indonesia ruptured perineum experienced by $75 \%$ In 2013 out of a total of 1951 births of spontaneous vaginal delivery, $57 \%$ of mothers received perineum stitches to aid in healing tissue (28\%) because of episiotomy and (29\%) because of a spontaneous tear (Depkes RI, 2013). 
Perineum conditions that affected by lokhea and it is humid is support for the proliferation of bacteria that can cause perineum infection. Along with the high incidence of rupture perineum, there should be good care so that the infection incident does not happen again. (Puspitaningtyas, 2009).

The development and research of perineal wound healing treatment methods say that the healing is not only can be done pharmacological, but also non-pharmacological been able to be developed, one of the alternatives that can be used is breastmilk. Admasari (2017) in the research entitled Breastmilk as an Alternative for Postpartum Perineal Care, showed that the use of breastmilk is more effective than the use of povidone-iodine in perineum wound care as it contains antiinflammatory, bioactive substances and growth factors that can help wound healing and prevention of infection, in addition, the use of breastmilk are harmless, free, available and sterile for perineal injury, this study also had received local permission of ethics research committees so that there are no aggrieved parties.

Results of a preliminary study in December 2018 in PONED Mangkubumi Public Health Care since October 2018 there were 11 deliveries and 7 of them suffered perineal rupture. $70-80 \%$ of postpartum mothers do wound carefully with soap and water and there is no healing alternative using breastmilk. Healing time is about 1 week or more. A preliminary study was also conducted to determine the amount of milk given to the wound by looking at the amount of breast milk at one time after a mother finished breastfeeding. The preliminary study's respondents were 5 postpartum mothers of 1 day, 5 days postpartum mother that can produce at least $2 \mathrm{cc}$ and most $3 \mathrm{cc}$ breastmilk, therefore the amount of milk for once wounds treatment is until the milk can absorb into the wound depends on the number of existing and based on the results of the previous literature review.

Based on the description above, the researcher is interested to research the effect of breastfeeding topical on perineal wound healing on 1-7 days postpartum mothers in Mangkubumi Public Health Center, Tasikmalaya.

Purpose. The purpose of this study is to know the effect of breastfeeding topical on perineal wound healing on 17 days postpartum mothers in Mangkubumi Public Health Center, Tasikmalaya.

Method. This research is using a pre-experimental design with the Static Group Comparison design. The sample in this research was determined by purposive sampling with respondents criteria, 2nd-degree perineal laceration, as many as 60 people, with 30 samples for the intervention group and 30 other samples for the control group.

The intervention group was given $0.25 \mathrm{cc}$ topical breastmilk for each treatment from 1-3 days postpartum mothers by dripping using a syringe without a needle by researchers and $2 \mathrm{cc}$ breastmilk from 4-7 days postpartum mothers by smearing the milk on cotton and compress it on the wound for 5 minutes. The control group performed 
self perineal care with an antiseptic soap. There are no restrictions for mobilization of the respondents in both groups

Measurement. Perineal wound assessment from day 1 to day 7 of post partum is using REEDA scale table (redness, edema, ecchymosis, discharge and approximation) each factor is given a score between 0 and 3 with a total score ranges from 0-15 (Alvarenga, et al, 2015). REEDA scoring scale, $0=$ good wound healing (good wound healing,), $1-5=$ poor wound healing (insufficient wound healing), $>5=$ bad wound healing (poor wound healing).

Ethical clearance to the Komite Etika Penelitian Kesehatan (KEPK) Tasikmalaya Health Polytechnic. The research permission has also been approved by the 6 of midwives at the Mangkubumi public health center and local $P M B$. All of the information regarding the purpose of research, voluntary participation, the research procedure, the benefits of research, risk and inconvenience, compensation, confidentiality, clarification, and willingness has been explained to all participants. 60 respondents were willing and signed a written informed consent.

This study using univariate analysis frequency distribution and bivariate analysis using Chi-square (X2).

Result and Discussions. Table 1 Frequency distribution of perineal wound healing at 1-7 days post partum mothers:

\begin{tabular}{|c|c|c|c|c|c|c|c|}
\hline \multirow{3}{*}{$\begin{array}{c}\text { Breastmilk } \\
\text { Topical }\end{array}$} & \multicolumn{6}{|c|}{ Perineal wound healing } & \multirow{3}{*}{$\begin{array}{c}\rho \\
\text { value }\end{array}$} \\
\hline & \multicolumn{2}{|c|}{ Well } & \multicolumn{2}{|c|}{ Poor } & \multicolumn{2}{|c|}{ total } & \\
\hline & f & $\%$ & f & $\%$ & f & $\%$ & \\
\hline $\begin{array}{c}\text { Do } \\
\text { (interventi } \\
\text { on) }\end{array}$ & 20 & 66.7 & 10 & 33.3 & 30 & 50.0 & 0,039 \\
\hline $\begin{array}{l}\text { Not done } \\
\text { (control) }\end{array}$ & 11 & 36.7 & 19 & 63.3 & 30 & 50.0 & \\
\hline total & 31 & 51.7 & 29 & 48.3 & 60 & 100.0 & \\
\hline
\end{tabular}

According to table it shows the effect of topical breastmilk on perineal wound healing in the intervention group and the control group.

At the end of the seventh-day assessment of the intervention group, showing the number of respondents with good wound healing more than the control group, as many as 20 people $(66.7 \%)$ while the control group 11 people $(36.7 \%)$. In contrast, at the end of the assessment of the control group indicates the number of respondents with poor wound healing more than the intervention group, as many as 19 people $(63.3 \%)$ and 10 people $(33.3 \%)$ of the intervention group.

Based on the analysis, the $\rho$ value $=$ 0.039 , so the result is $\rho$ value $(0.039)<\alpha$ (0.05), then $\mathrm{Ho}$ is rejected and $\mathrm{Ha}$ accepted, it means there is a significant effect of breastmilk topical use on perineal wound healing.

The application of breastmilk topical in the intervention group is more influential than the use of antiseptic soap in the control group. This is because breastmilk contains very useful components to help wound healing and prevention of infection, the antiinflammatory molecules, bioactive substances, and growth factors (Admasari, 2017). 
Breastmilk in humans remains a unique and high standard for health, in this present study will discuss the advantages of breastmilk in medical treatments, one of them is an alternative medicine in perineal wound healing.

Topical breastmilk, especially colostrum is rich in substances of antibody, anti-inflammatory, and leukocytes that play a role in pressing the colonization of pathogenic microorganisms, which can cause wound infections and accelerate the healing time (Subiasturik, 2011).

The protein content is very high in colostrum, serves as an essential bondforming body. Proteins that are in colostrum and breastmilk binds to proteins in the wound so that it forms an immune reaction and apoptotic process (mechanism of programmed death cell) (Laksawati, 2009) cited in Sofiana and Agustina, 2013).

At the time of the initial formation of the wound, bits of hemostasis blood components release and activate cytokines consisting of Epidermal Growth Factor (EGF), Insulin-like Growth Factor (IGF-1 and IGF-2), Granulocyte-Colony Stimulating Factor (G-CSF), which have a role in cell proliferation, Platelet-derived Growth Factor (PDGF) and Transforming Growth Factor Beta (TGF- $\beta$ ), which play a role in chemotaxis of neutrophils, macrophages, mast cells, endothelial cells and fibroblasts (Greeting in Olivia, 2013). Cytokines in breastmilk "communicate" with the cell to affect immune activity.

TGF- $\beta$ family of cytokines in human milk is the most abundant and consists of three isoforms, dominated by TGF$\beta 2$. TGF- $\beta$ can regulate inflammation, wound repair, and help prevent allergic diseases, involved in normal cell activity in embryonic development, cell proliferation, and tissue. In this phase occurs vasodilation and accumulation of Polymorphonuclear leukocytes (PMN). Platelets aggregate will produce inflammatory mediators, namely Transforming Growth Factor Beta 1 (TGF- $\beta 1$ ), which was also produced by the macrophages. TGF- $\beta 1$ then activates fibroblast which aims to synthesize collagen.

The results of perineal wound healing in the intervention group are better than the control group. It is also because of the content of antiinflammatory molecules that exist in breast milk. Breast milk contains antiinflammatory molecules called ProResolving Mediators (SPM) who worked as bioactive substances. These molecules are useful for wound healing, particularly in injury recovery.

Another composition in milk that plays a role in the inflammatory phase is breast milk glycoprotein form of Lactadherin, after infection or damage, cadherin-mediated phagocytic uptake of apoptotic cells and stimulates a signaling cascade resulting in a reduction of inflammation through the blockade of TLR4 and NF- $\kappa \mathrm{B}$ signaling. Lactadherin increases during inflammation in wound healing (Aziz in Olivia, 2013).

Furthermore, breastmilk, epidemiologically and clinically contain ingredients that serve to regulate the immune system and antioxidants such 
as vitamins $\mathrm{A}, \mathrm{C}, \mathrm{E}$, alpha antitrypsin deficiency, cortisol, prostaglandins $\mathrm{E}$ cytokines, catalase enzymes, inhibitors enzyme, glutathione peroxide, and platelets activator factor (Riordan, 2016).

Breastmilk in its compositions are leukocytes, which consist of $90 \%$ macrophages and 10\% lymphocytes ( $\mathrm{T}$ lymphocytes and B lymphocytes). Macrophages have phagocytic function against pathogens. While the $\mathrm{T}$ and $\mathrm{B}$ lymphocyte function is antibody synthesis. Sig A in colostrum and breast milk is believed to protect against various infections (Subiastutik, 2011).

The control group treatment is using an antiseptic soap, which only contains Chloroxylenol while breast milk is very rich in bioactive substances, antibodies, anti-inflammatory and growth factors that play a role in suppressing colonization of pathogenic microorganisms that can cause wound infections and accelerate the healing time (Subiasturik, 2011).

Based on the description above and supported by previous studies, the researchers used breast milk as an alternative to perineal wound healing, because the biomolecular processes in the process of wound healing and wound infection prevention, can be mediated by a variety of bioactive compounds, growth factors and immunological existing content in breast milk.

Conclusions and Suggestions. There is an effect of breastmilk topical on perineal wound healing on 1-7 days postpartum mothers in Mangkubumi Public Health Center Work Area with $\rho$ value 0,039.This study can be a reference for the development of science in the future studies.

\section{References}

Admasari Y, et al. (2017) Demonstrate Admasari Y, et al. (2017) Breastmilk As An Alternative For Postpartum Perineal Care. Belitung Nursing Journal , Volume 3, Issue 33(3):238-245.

Allam, NA., Wafa, A., Talat, AM (2015) The Effect of Topical Application of Mother Milk on Separation of Umbilical Cord for Newborn Babies. American Journal of Nursing. 4(5):288296.

Alvarenga, Mariana, et al. (2015). Episiotomy Healing Assessment: Redness, Oedema, Acchymosis, Discharge, Approximation (REEDA) Scale Reliability. Revista Latino-Americana de Enfermagem. DOI : 10.1590/0104-1169.3633.2538

Ambarwati, Wulandari (2010) Asuhan Kebidanan Nifas. Nuha Medika: Yogyakarta.

Anggraini, Y (2010) Asuhan Kebidanan Masa Nifas. Pustaka Rihama : Yogyakarta.

Anggraeni (2016) Hubungan Berat Bayi dengan Robekan Perineum pada Persalinan Fisiologis di RB Lilik Sidoarjo. Jurnal Ilmiah Kesehatan. 9. (1): 91-97.

Astutik (2014) Payudara dan Laktasi. Salemba Medika : Jakarta

Bahiyatun (2009) Buku Ajar asuhan Kebidanan Nifas normal. EGC : Jakata.

Baradero, et .al (2008) Prinsip dan praktik keperawatan perioperatif. Buku Kedokteran EGC : Jakarta. 
Bick DE, et.al (2010) Perineal assessment and repair longitudinal study: protocol for a matched pair cluster trial. BMC Pregnancy and Childbirth. (10):1-8

Boyle (2008) Pemulihan luka. EGC : Jakarta.

Cunningham (2013) Obstetri Williams. EGC : Jakarta.

Dahlan, Sopiyudin (2009) Statistis Untuk Kedokteran dan Kesehatan. Salemba Medika: Jakarta.

Depkes RI (2009) Profil Kesehatan Indonesia. Kementerian Kesehatan RI. Jakarta

Depkes RI. (2017) Profil Kesehatan Indonesia tahun 2016 -2017. Tersedia di www.depkes.go.id/resources/do wnload/pusdatin/.../ProfilKesehatan-Indonesia-2016.pdf. Diakses tanggal 15 Oktober 2018.

Depkes RI (2017) Pusat Data dan Informasi Kementerian Kesehatan RI, Angka kematian ibu .Tersedia di http://www.depkes.go.id/resour ces/download/pusdatin/infodati n/infodatin-ibu.pdf. Diakses 15 Oktober 2018.

Dorland, WAN (2010) Kamus Kedokteran Dorland. Edisi 31. EGC: Jakarta.

Hamilton, Persis M (2002) Dasar dasar keperawatan maternitas. EGC : Jakarta.

Hoda Abed, et .al (2012) Effect of Self Perineal Care Instructions on Episiotomy Pain and Wound Healing of Postpartum Women. Journal of American Science ;8(6):640650].(ISSN:1545-1003).

Infodatin Pusat Data dan Informasi Kementerian Kesehatan RI
(2014) Situasi dan Analisis Asi Eksklusif. Jakarta

Jones, Derek (2002) Dasar - dasar obsteri dan gynekologi, Edisi 6. Hipokrates : Jakarta.

Kurniarum (2015). Keefektifan Penyembuhan Luka Perineum pada Ibu Menggunakan Dauh Sirih. Jurnal Terpadu Ilmu Kesehatan, Volume 4, No 2, hlm 82- 196.

Mansyur (2014) Buku Ajar: Asuhan Kebidanan Masa Nifas Dilengkapi Penuntun Belajar Nurliana Mansyur. Selaksa Medika : Malang.

Manuaba, I (2010) Ilmu Kebidanan, Penyakit Kandungan, dan KB. EGC: Jakarta.

Mochtar (2010) Sinopsis Obstetri Fisiologi Patologi. 3rd Edition. ECG : Jakarta.

Nasution, N (2011) Faktor-Faktor Yang Berhubungan Dengan Terjadinya Ruptur Perineum Pada Ibu Bersalin Di RSU Dr Pirngadi Medan Periode Januari-Desember 2007. (KTI)m Universitas Sumatera Utara Medan

Notoatmojo (2010) Konsep Perilaku Kesehatan, Promosi Kesehatan, Teori dan aplikasi. : Jakarta.

Nursalam (2008) Konsep dan Penerapan Metodelogi Penelitian Ilmu Keperawatan, Pedoman Skripsi, Tesis dan Instrumen Penelitian Keperawatan. Salemba medika : Jakarta.

Olivia, Ballard., Ardythe, L., Morrow (2013) Human Milk Composition Nutrients and Bioactive Factors. Pediatr Clin North; 60(1): 49-74.

Pengembangan Kesehatan (Badan Litbangkes) Kemenkes RI (2017) Angka Kematian Ibu 
Lembaga Penerbit Badan Litbangkes. Tersedia di www.depkes.go.id/resources/do wnload/...2019/7.\%20Badan\%2 0Litbangkes.pdf. Diakses tanggal 15 Oktober 2018.

POGI dan JNPK-KR. (2017) Buku Acuan Asuhan Persalinan Normal. JNPK-KR.: Jakarta.

Prasetyawati, A.E (2011) Ilmu Kesehatan Masyarakat. Nuha Medika : Yogyakarta.

Prasetyawati, A (2012) Kesehatan Ibu dan Anak (KIA) dalam Millenium. Development Goals $(M D G ' S)$. Nuha Medika : Yogyakarta.

Prawitasari (2015) Penyebab Terjadinya Ruptur Perineum pada Persalinan Normal di RSUD Muntilan Kabupaten Magelang. Jurnal Ners dan Kebidanan Indonesia. 3. (2): 7681.

Puspitaningtyas, A.H., Harjanti, A.I (2009) Hubungan Tingkat Pengetahuan Teknik Perawatan dengan Kesembuhan Luka Perineum pada Ibu Nifas di Kota Semarang. Jurnal Dinamika Kebidanan, 1(2):1-11.

Riordan, Jan et all (2016) Breastfeeding and Human Lactation Fourth Edition

Rizki, S (2010) Faktor-faktor yang

Berpengaruh pada

Penyembuhan Luka SC. Jurnal Unimus. 98-104

Rukiyah. (2010) Asuhan kebidanan. Trans info media : Jakarta.

Saifuddin, Abdul Bari (2005) Ilmu kebidanan. PT Bina Pustaka Sarwono Prawirohardjo : Jakarta.

Saifuddin (2007) Buku Panduan Praktis Pelayanan Kesehatan Maternal
\& Neonatal. PT Bina Pustaka Sarwono Prawirohardjo : Jakarta.

Saifuddin, Abdul Bari (2007) Ilmu kebidanan. PT Bina Pustaka Sarwono Prawirohardjo : Jakarta.

Saifuddin, Abdul Bari (2008) Ilmu kebidanan. PT Bina Pustaka Sarwono Prawirohardjo : Jakarta.

Saifuddin, Abdul Bari (2009) Ilmu kandungan. PT Bina Pustaka Sarwono Prawirohardjo : Jakarta.

Saleha, Siti. (2009) Asuhan kebidanan pada masa nifas. Salemba medika : Jakarta.

Saleha (2009) Asuhan Kebidanan Pada Masa Nifas. Salemba Medika : Jakarta.

Setiadi (2007) Konsep dan Penulisan Riset Keperawatan. Graha Ilmu Sugiyono : Jakarta

Shadini (2012) Penyakit Wanita. Citra Maya Yogyakarta.

Sloane, Ethel (2016) Anatomi dan Fisiologi untuk Pemula. EGC : Jakarta

Smeltzer, S.C. (2002) Buku ajar keperawatan medikal bedah. EGC : Jakarta

Sofiana , I., Agustina, EE (2013) Efektifitas Metode Kolostrum dan Metode Kasa Kering Terhadap Waktu Pelepasan Tali Pusat di BPS Ny. Endang Purwaningsih dan BPS Ny. Istiqomah Kecamatan Rakit Kabupaten Banjarnegara Tahun 2011. Jurnal Bidan Prada. 2(02).

Suryani (2013) Faktor-Faktor yang Berhubungan dengan Ruptur Perineum Pada Persalinan Normal di Rumah Bersalin Atiah. Jurnal Kesehatan. IV. (1): 277-283. 
Suradi, R., Hegar, B., Partiwi (2010). Indonesia Menyusui. Jakarta: Balai Penerbit IDAI. 2010.

Suwiyoga. (2004) Gejala-gejala dan Infeksi Masa Nifas. Salemba Medika : Jakarta.

Syalfina (2016) Faktor Yang Berpengaruh Terhadap Penyembuhan Luka Perineum Pada Ibu Nifas. PROSIDING IAKMI : JABAR.

Trisnawati (2012) Asuhan Kebidanan. Jilid I. PT. Prestasi Pustakarya : Jakarta.

Valentine, CJ, et .al (2012) Breastfeeding in women with severe preeclampsia. Breastfeed Med. 7(6);457-463

WHO (2017) World Health Statistics 2017 Monitoring Health For The SDGs Sustainable Development Goals. Tersedia di http://apps.who.int/iris/bitstrea $\mathrm{m} / \mathrm{handle} / 10665 / 255336 / 97892$ 41565486-

eng.pdf;jsessionid=04A8A9723 E1DD0F519114FBEB30D7495 ?sequence $=1$. Diakses tanggal 15 Oktober 2018.

Wiji, RN (2013) ASI dan Panduan Ibu Menyusui. Nuha Medika : Yogyakarta

Winkjosastro G. (2005) Ilmu Kebidanan. Yayasan Bina Pustaka Sarwono Prawiroharjo : Jakarta.

Winkjosastro. (2007) Ilmu Bedah Kebidanan. Yayasan Bina Pustaka Sarwono Prawirohardjo : Jakarta.

World Health Organization, UNICEF (2009). Breastfeeding counselling. A training course. Geneva: WHO 